Retraction

\title{
Retracted: Signal Parameters Estimation and Optimization Using Mobile Navigation Data
}

\author{
Mathematical Problems in Engineering
}

Received 10 May 2021; Accepted 10 May 2021; Published 28 May 2021

Copyright @ 2021 Mathematical Problems in Engineering. This is an open access article distributed under the Creative Commons Attribution License, which permits unrestricted use, distribution, and reproduction in any medium, provided the original work is properly cited.

Mathematical Problems in Engineering has retracted the article titled "Signal Parameters Estimation and Optimization Using Mobile Navigation Data" [1], due to concerns that the submitting author, Luxi Dong, did not obtain permission from the coauthors prior to the submission and publication of the article. Luxi Dong has clarified that they did not make a significant contribution to the study and the study was completed by Jiyuan Tan and the other coauthors. All listed authors agree to the retraction of this article for the above reasons.

\section{References}

[1] L. Dong, X. Liu, M. Jia, J. Tan, and X. Wei, "Signal Parameters Estimation and Optimization using Mobile Navigation Data," Mathematical Problems in Engineering, vol. 2020, Article ID 8898938, 15 pages, 2020. 